\title{
PROCESS MAPPING AND FEASIBILITY OF IT'S PRACTICAL IMPLEMENTATION WITHIN THE PUBLIC ADMINISTRATION IN SLOVAK REPUBLIC
}

\section{aMAREK ARENDARČÍK MÚČKA}

Dell Halle GmbH, Raffinerie Str.28, Germany

email: ${ }^{a}$ marek.a.mucka@gmail.com

Abstract: This article deals with the process mapping which is applied as a tool ibsroving the effectiveness of public a improving the effectivens the The author summaizes the gained theoretical knowledge from the field where he focuses mainly on process classification and process management. Author performed a pilot NPS survey and analyses the key outcomes. As well he formulates the recommendations with the aim to drive the process improvement and optimization in
the public sector.

Keywords: public administration, process mapping, financial effectivity, process management, process improvement, customer satisfaction, net promoter score.

\section{Introduction}

The public administration in Slovakia is influenced by number of the factors affecting its operation. We may report the multifactorial influence or the specific factors as in particular the innovations, new technologies, economical, organizational and managerial ways of guidance and so on. Many trends and changes are directly impacting the activities of the public administration organizations and represent new challenges which the public administration has to deal with. And then it is only the matter of the particular organizations, management and the emploeés how they approach the issue.Our article presents the trend concerning the transition from the functional management to the process management within the public administration. The trend substantially consists of the process mapping and its subsequent optimization emphasising the positive economical aspect leading to the inside of the organization where, on one hand, we are talking mainly about the process ownership, economical contribution, advisability, transparency, efficiency of the respective actions and on the other hand, we are talking about the direction outside to the specific output in the form of satisfied clients, the consumers of the service provided by the public administration bodies in selected authorities within Slovakia.

\subsection{Process and the process mapping}

There are many definitions of the process and we are choosing the definition actual for the self-government. According to Nenadál (2001) and team the process is a limitted group of mutually linked working activities of predefined inputs and outputs. Its commencement and the end are clearly and acurate defined. The inputs always represent the defined input parameter and the outputs are the result of the process activities. The initiation of the process, its running activity and the process end are specified and the same another related sequent processes. The outputs need to be compared: real versus required. In terms of gaining the rational results and giving the satisfaction to the customers - citizens it is necessary to manage the processes. The key tool of understanding the flow of the processes is the mapping of them. The process maps provide us with a complex scheme of the process and in particular it is shown in mutual connections. The process mapping is the communication tool of the process management (Fiala, J., Ministr, J., 2003, p.89). The process map shows the description of the processes, the inputs and the outputs, and the parameters monitoring the processes. During the process mapping as per Šmída (2007) we strive to find especially the following: The role of the process, its products and whom they are assigned to, where and by what the process starts and terminates, what processes are mutually connected and how they are interlocked, the flow of basic sub-processes and of their activities, the sections where the process is taking its course, the inputs consuming by the process (including IT), the inputs and the outputs of any activity, the responsibility for the activities, the sub-processes and the processes.
A process map shows the input-output relations of the process activities and the bodies. By means of the process sequence chain are executed the activities needed for the inputs transformation to the outputs. (Fiala J., Ministr J., 2003, p. 12). Through the process mapping it is feasible to identify the critical interfaces and the time overlapping the sub-processes. In some cases there are also the weak points, irrational and absent or unnecessary activities. The process map enables the documentation and the understanding of not only the actual process. By the subsequent detailed analysis we may, above all, refer to the inadequacies. And by subsequent implementation of new activities, process steps and proposed solutions or by elimination of unnecessary or ineffective process steps and activities we are able to elaborate a new process map serving as the reference document of specific organizational unit. Basically the process map may be created and modified only by the process owner, or the dedicated process operational team.

The key items of the process mapping according to Fiala and Ministr (2003) are as follows: i. the graphical presentation of the elements (objects, information) and activities (manual or automatic) the purpose of which is the proper and transparent presentation, ii. the process map has to provide the evidence of the activities to be realized by the system and based on the proposed specific system, iii. the process map should be consistent and hierarchic - the main activities on the highest level and the details on the lower levels, iv. logging of any resolution and continuous assessment of the process map development.

The term process mapping, generally indicated as the basic element within the process of transformation from strategic to operational, can be found both in private sphere and in public administration. The lawmaker or the rule maker, eventually the management specifies the desired statuses which are to occur and, in principle, it is transformed to the real life. Then the role of the respective organizations and the organizational units and their employees is to realize the operational activities needed for making the generally defined and desired statuses applicable and executable in practice. The creation of transparent and especially correct process maps is realized by utilization of the graphical presentation. In contrast to the verbal description the graphical presentation is more formal and of higher expectation that the process will be understood by various persons or by operational teams likewise. The process, the activity, impulse and the relation are the basic elements of any model / process

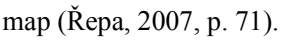

Several graphical presentations with related methods are in existence. Thus we may report not only simple operational realization but also the sequence of the process activities of high rate of repeatability where the operation assumes the particular activities within concrete situations and not marginalizing the fact, that any situation which may occur cannot be both mapped and described precisely. From that reason it is important to let the operational authority to make the resolutions of the concrete situations and to apply the most appropriate solution for final service customer and currently to respect the terms specified by the lawmaker resp. the rule-maker. This flexibility of making decisions is considerable mainly in term of the effectiveness since it expects that by providing the reasonable rate of decision-making of the concrete situation enable more effective, better and faster decision and will avoid the stalemate situations when the employee could not know the fix or he could not realize the action as far as the process does not expect it.

At this stage we would like to highlight the Capability Maturity Model Integration (CMMI) which divides the processes of the organizations according to the level of its maturity. Not existing: no process exists and the organization does not notice any problem. Under occurrence of the respective actual situations the reactions of the organization and its units are 
spontaneous. Incidental: is disposed by any organization with undefined own processes. The activities are solving by ad-hoc approach and based on the respective officers knowledge. Presumably it is possible to see the problems. It is objective that the organization is successful only at the cost of enormous working effort of the individuals. Repeatable: only intuitive - an effort to create the standard processes exists. There are identified the main characteristics of the performance of the processes to be realized. Formalized: Defined and described are the courses of activities and the same of the inputs and of the outputs. Possible problems among the activities are solved during the definition of the process and not at the termination of it. Measurable: an added management and control process. The real data on the process running are collected and resulting in the measures determined by the management. Optimized: the process is of the best probable state thanks to continuously improving processes and thanks to the observation of the best practices within other organizations. The source of the activities intended to optimize and to eliminate the failures and the causality is the standard component part of the process (Basl, 2008, p.115).

\subsection{Process management and it's contribution to public} administration

The contributions of the process managing are manifesting in all sections of the organizations within the public administration. So that the organization could be successful the process management must be implemented by it and its employees need to be allowed to improve and to amend the working processes creating the basis of overall increased efficiency of the organization regardless of either private or the public sphere. The transition from functional management to the process management is the assumption of it. In generally may be stated that it is needed to provide the individuals, the operational teams or the groups within the organization or out of it, with the access to the relevant information and with the ability to measure, analyze and then to evaluate the results of implemented processes tending to the achievement of the aims of the organization in general. The aim of the organization activities should motivate the individuals or the operational teams to eliminate the surplus, unnecessary and ineffective process activities but rather to perform the critical and important process activities and to make it more effective for the purpose of the faster gaining of the aim. The top management of the organization has to define the clear long-term and short-term strategies so that the individuals could identify the aims and may perform the change from the strategic to operational. The practice shows the examples where the process changes are tested by small so called pilot teams. These teams are sufficient for making the statement regarding the success of the process change and they review the desired or non-desired results. The small in advance specified sample is enough for testing of all relevant activities and for reporting the found measurements, methods, results and the costs that may be, where necessary, applied within the larger organization the process alteration is designed for. The efficiency of applied processes has to be monitored and measured continuously on defined interval basis. If a positive trend occurs it needs to be analyzed and quantified backwards - the need of the route cause analysis. The critical step which represents the highest contribution must be appointed and consecutively repeated to validate it is not an incidental event. In case of the negative trend the critical activity of the existing process needs to be changed. After that we can continue to measure further results. Consequently we may essentially state if the aim is completed or if it is not completed.

Pursuant to BPI manual with creating the processes it is necessary to follow several principles as per so called SMART methodology. In particular to enforce the fact that the aim we are striving to reach through the process should be; i.: specificwe are able to specify its term and to identify it; ii.: measurable - the conditions and the tools of measurement must be created and then it is possible to report the results of the activities; iii.: achievable - the defined goal should be obtained by us through chosen working practice; iv: realistic - the aim should be obtainable under either existing conditions or under the conditions altered by the process; v: time bound- the period of our striving to obtain the goal should be timely limited.

\section{Net promoter score (NPS) as a process improvement tool}

According to Owen and Brooks (2008) the net promoter score (NPS) may be defined as the most progressive methodology of the observation of the loyalty. The NPS initially represented an important task implemented in the observation of the companies and their client mutual relations. The pioneer of the net promoter approach Reichheld (2003) stated that this enabled to express what lot of companies intuitively understood, that within their client basis exist the persons contributing the growth of the company by their both purchasing behaviour and their recommendations (the promoters); and another person's preventing the growth of the company by their negative recommendations (detractors) and finally the persons representing the unrealized opportunity (passive promoters). We assume that this methodology is feasible within the public administration too. Particularly the task of NPS is to find the reasons of the client dissatisfaction and then through the specific measures to contribute the remedy, the improvement and the consistent growth.

Thus the NPS is not a terminal station and it is an indicator enabling to initiate the measures tending to the improvement of the internal processes openly influencing the overall future clients' satisfaction. It is feasible based on gained both the respective figures and the clients' feedback. The public administration does not produce the specific commodities but it provides the service. In particular it is important to make a qualitative analysis of the provided service. The way of providing the service is not settled by the legislation. The legislation arranges only the fact that the service has to be provided or that it may be provided. The basic difference in comparison to the private sphere is that the citizen, in most cases, may not choose the provider of the service optionally. The citizen is entirely dependent on the authorized body. As the citizen/client has mostly no alternative option it may be named as quasi „market monopoly position of the public administration body,.. In contrary to the private sphere the public administration authorities are not competitive. The public administration authorities primarily are not tending either to the generation of the profit or to the economic growth. Consequently the practice does not show that the clients dissatisfied with one office shall turn to the office with better reference or to another one with what the clients' previous experience was positive.

Tab. 1: Key differences/similarities between public administration and private sector in terms of NPS approach

\begin{tabular}{|c|c|}
\hline \multicolumn{2}{|c|}{ Key differences /similarities } \\
\hline Private sector & Public administration \\
\hline Growth & The growth cannot be measured \\
\hline Competition & Very limited competition \\
\hline Process approach & Lack of process approach \\
\hline Effectiveness & Effectiveness \\
\hline Loyalty & $\begin{array}{l}\text { Very limited possibility to measure } \\
\text { loyalty }\end{array}$ \\
\hline Customer satisfaction & Customer satisfaction \\
\hline Inclusion of employees & Inclusion of employees \\
\hline Efficiency & Efficiency \\
\hline Inclusion of clients & Inclusion of clients \\
\hline Quality & Quality \\
\hline Managerial functions & Managerial functions \\
\hline Innovations & Innovations \\
\hline
\end{tabular}

Source: Author's elaboration

The table 1 shows our opinion regarding the key differences/similarities of both sectors especially we want to expand on the competition piece at this stage. In general we cannot say that there is absolutely zero competition in public sector. We have to consider the specifics of the authorities which are dealing with social service facilities. Let's take the example of the retirement homes. Most frequently the founder is a certain regional authority. This authority may both to define and to implement its own original end to end concept of a retirement home. Such concept may differ from other concepts in a positive 
or negative way. As well a retirement home is not bounded with territorial or material scopes. With that said a pensioner can freely decide only based on his own judgment or available references if the particular retirement home satisfies his needs and/or the desired standard of services. On the other hand a building authority cannot implement its own concept neither can acquire citizens from other districts. Pursuant to the provisions of law a building authority has to provide a service within a particular territory and to the specific group of individuals. With that said that the citizen whose permanent residence is the town of Vel'ké Kapušany cannot deal with the building authority in any other town or district. The Building authority in Vel'ké Kapušany is the only appropriate authority. Another good example of possible competition between authorities might be the activity in the sphere of the confirmations. Any town authority issues an authentication of a signature. And the notary may do the same. Here we can see a clear mutual overlap of both the private and the public sectors and the possible competition between the authorities. The authorities can be competitive regarding the provided levels of quality and service, required time spent, distance nevertheless with pricing. In our point of view the lower price and the required time spent are the most competitive advantages in comparison to private notaries. In terms of the process approach the private sector especially the transnational corporations are using the process approach in a very good way making sure they are optimizing their processes to meet the customer demands. In the public administration we rarely see this approach in the authorities operations and customer facing roles or departments. On the authority's side the lack of process understanding and the non-ability properly and simple to explain to the client what needs to be done results in the multiple visits. We believe that the multiple visits increase the costs; required time spent and is decreasing the effectiveness and quality of the particular authority. Our small NPS pilot in Vel'ké Kapušany presents the fact that the authorities should focus on reduction of multiple contacts needed to fix the clients demand. If a certain case needs one contact to be arranged and we observe that other same cases need significantly more contacts to be closed then the authority has the process issue which needs to be dealt with. The authority needs to apply the root causing to identify the gap and to work on a solution.

Regarding the terms of the loyalty, in our point of view the client has no other choice then to deal with the appropriate authorities according to law with few examples of exceptions we have described earlier. Moreover we believe that the inclusion of clients can be very helpful to the authorities in public administration. The client's feedback can be and should be used for increasing the quality of the provided service in the way leading to full client's satisfaction. Many clients are willing to share their experience and are pointing out the process gaps, unnecessary bureaucracy, inefficiency, unwillingness and indifferences of employees in solving the client's problems, lack of information sharing, lack and level of communication etc. All the above detailed feedback of the clients may improve the functioning of the particular organization. We believe the innovations are crucial for customer satisfaction either. Transfer of the information between the authorities, online databases with necessary up to date information, particular forms available for downloads, ability to arrange at least some matters online etc. need to become a must have otherwise the New Public management will remain only a theory in Slovak republic

\subsection{Practical application of the NPS in public administration - applied methodology}

The NPS is calculated as the difference between the net promoters and the critics (detractors) of the existing particular company. The promoters and the detractors ratio was found on the basis of the responders representative sample answers to the question "How likely would you recommend the company products and the service to your friends and known persons?" The answers were measured through the scale in the range from 0 (I absolutely do not recommend) up to 10 (I do highly recommend). The responders with the answers 9 and 10 were specified as the net promoters. The responders answering in the range from 0 to 6 were specified as the critics. The responders answering between 7 and 8 were specified as neutral or the passive promoters. Then the overall NPS was calculated through the pattern: NPS = net promoters (\%) - critics (\%). The range of the NPS values may be between plus 100 and minus 100 .

Tab. 2: NPS score of the Town office Vel'ké Kapušany

\begin{tabular}{|c|c|c|}
\hline NPS $=35,3 \%$ & $\begin{array}{c}\text { Town Office Vel'ké } \\
\text { Kapušany }\end{array}$ & $\begin{array}{c}\text { July-September } 2014 \\
N=105\end{array}$ \\
\hline net promoters & $52,3 \%$ \\
\hline passive promoters & $30,5 \%$ \\
\hline detractors & $17,1 \%$ \\
\hline
\end{tabular}

Source: Author's elaboration

At Vel'ké Kapušany Town Office was realized the NPS inquiry from June to September 2014. The sample consists of 105 responders the clients of the Town Office who were asked to complete the anonymous questionnaire of 10 questions right after the termination of the communication with the officer. All completed questionnaires were scanned and filled with the registry. Regarding the answer to the ultimate question „How likely would you recommend the products and the service of the office to your friends and well known persons?" 55 responders i.e. 52,3\% indicated the score 9 and 10 (the range was from 1 to 10 ) where 1 means I should absolutely do not recommend and 10 means I should strongly recommend. These responders were ranked as the net promoters. Other 18 responders i.e. $17,1 \%$ answered this question in the range from 1 to 6 . These responders were ranked as the detractors. And 32 of responders i.e. $30,5 \%$ answered this question in the range from 7 to 8 whereby they were included to the group of either neutral or passive promoters. Vel'ké Kapušany Town Office overall NPS score $=35,3 \%$.

\subsection{NPS pilot project in Vel'ké Kapušany}

Together with Dr. Gyimesi the head of the Town Office Vel'ké Kapušany we elaborated the questionnaire and then the employees, after finishing their work with client, submitted the questionnaire to the client for the completion. The questionnaire was anonymous and besides other 9 questions it included also the ultimate NPS question utilized at the private sphere questioning: "To what extent would you recommend this office products and service to your friends and well known persons?" The questionnaire consists of 10 questions, 8 of them are of the scale from 1 to 10 and two questions are of yes/no types of answers. In spite of the fact that within the public administration the clients have mostly no option to choose the office arranging their matters we believe that the clients' answers are of sufficient value for consideration of the extent of the clients' satisfaction regarding the public administration authority service. Along with the clients' satisfaction with the service of the authority we were establishing also the opinions of the Hungarian nationality citizens regarding their satisfaction with application of the Hungarian language at Vel'ké Kapušany Town Office and how many of them are demanding to process their official business in the language of this national minority. This analysis is essential also in relation to legitimacy of stronger striving of Hungarian political representation regarding the strengthening of the national minority member language rights. In close future we want to realize other NPS inquiries at chosen authorities and to compare it. Within the public administration the sense of NPS is to gain the client information repeatedly, to make the analysis of it and systematically eliminate the addressed failings and gaps. 


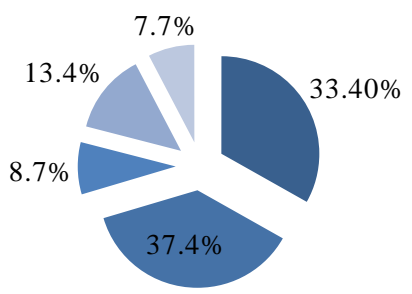

" $12 \square 3-3-5 \square+$

Fig. 1: How many times did you visit this office until you arranged your mater? (Author's Elaboration)

The question accentuated by us was the question No.9 „How many times did you visit this office till you arrange your matter?" Only 33\% of the responders said that they were able to arrange their mater successfully for the first time. The responders counting $37 \%$ needed two visits to arrange their matters and almost $30 \%$ of the responders needed 3 and more contacts to arrange their matters. We believe that the marked reduction of the numbers of the contacts resp. the less personal visits of the client needed for arrangement of the respective mater shall contribute the higher client satisfaction. It should be applicable the less contacts needed for arranging the respective matter the higher is the client satisfaction with the service provided by the office. The aim should be the arrangement of the matter for the first time. For this it is necessary to adjust the officers' way of work and to verify the most often reasons of the repeated contacts regarding the same matter and to minimize these contacts through the adequate and targeted measures.

\section{Process management - levels of organization maturity}

Further on we will describe the maturity of the organizations within the public administration. The lowest level (1) represents the chaos and the absence of any process within the organization. Within the public administration in Slovakia no organization should be at this level and it has to realize all necessary activities to occur on the top of the pyramid. This lowest level is absolutely unacceptable and inconvenient within the public administration in Slovakia. The next level (2) represents the legislation, enactments and the rules i.e. the level where the work of the organization consists of specific even not satisfied process level and with particular method or several procedures. We do not recommend this level too since we are regarding it insufficient, ineffective and absenting a structural process solving for operation of the effective organization. Next level (3) is representing by documented process maps where the organization has a detailed overview of its processes however this situation, by itself, does not resolve the problem of the efficiency of the organization. The sole documentation of the processes is not a systemic solving but it is one of the first and basic steps. It is an important milestone on the way to improved and more effective processes within the organization. This third level is not recommended by us too. The fourth stage represents the level where the organization applies the concrete key process indicators (KPI). Based on the predefined criteria and then on performed measurements the organization is capable to monitor and to interpret its processes. This level includes the benchmarking and we recommend it. The final and the highest fifth level represents the continuous process improvement (CPI) and on this, by us recommended highest level, we are expecting a continual activity of the organization and not only a simple ad hoc action. Based on the particular process activities, remedies, measures, arrangements and changes the organization continues to simplify, to improve and to make its activity more effective. This level expects the method of the „best practice sharing“ by the organizations and by the respective organizational units. Within the public administration the aim of any organization should be to achieve this mentioned status. Moreover, in the fields where it is applicable, the public administration has to adopt the successful models of the private sector and to approach the public administration more closely to the citizen who is the final consumer of its service. The feedback provided by the citizens should serve to the public administration as an impulse eliminating the process limitation, the deficiencies, the excessive bureaucracy and inefficient resolutions and on the contrary it should start or continue to support the activities evaluated by the citizens as useful and positive ones. In the direction inside the public administration we recommend to realize an investment to the educational process of its employees and to enable their careers so they become the experts in their positions. The same we recommend to revalue the actual way of making the assessment of the public administration employees interested in and requiring the process change perhaps even positive contributing the process changes however the conditions under which they are working are not favorable and have no background. The absence of both the support and the development are resulting in the loss of the employees' motivation to perform the changes for the benefit of the organization.

\section{Conclusions}

The process approach and the adequate process mapping is a practical and useful tool also in the public administration. The processes within the public administration has to be optimized both in inside and in outside directions. Although the process owner should reflect the specifics in the state or selfgovernment, the correct implementation and usage of the process mapping can be in general an asset for any organization within public administration. In particular it is related to the improvement of provided service; the simplified procedures; an rapid, transparent and easy access to the essential information; the option of an accelerated procedure for an extra payment; the consultations and so called ,end to end approach“. It is critical to make sure that the implemented processes are not definite and process owner may amend the existing process where necessary so that it reflects the changing environment. As far as the employee of the public administration is limited by the legislation arranging the state to be occur and not the way how to realize it there is offering a feasibility to apply the process mapping in terms of gaining the demanded changes right here. Management of the particular organization has to support any effort related to process approach incl. the implementation of the process mapping in a way leading to success and contributing the customer satisfaction which is the outcome of the service. We also believe that the implementation of maybe slightly amended net promoter score methodology in public administration will be an asset for any organization in terms of feedback and customer needs. NPS is basically articulating the voice of the customer and this voice must be heard also by the organizations in the public sector.

\section{Literature:}

1. Basl, J., Tuma, M., Glasl, V.: Modelování a optimalizace podnikových procesu, Západočeská univerzita, Plzeň, 2002. p.140 ISBN 80-7082-936-2.

2. Fiala, J., Ministr, J.: Prúvodce analýzou a modelovaním procesú. Ostrava: Vysoká škola baňská - Technická uviverzita, 2003. p.109 ISBN 20-248-0500-6.

3. Nenadál, J.: Měření v systémech managementu jakosti, Praha: 2001, p.310. ISBN 80-7261-054-6.

4. Owen and Brooks, Answering the ultimate question: how net Promoter can transform your business, San Francisco, YosseyBass, 2008.

5. Reichheld, F.F.: The one number you need to grow, Harward Business review, 2003 p. 46-54,

6. Šmída, F.: Zavádění a rozvoj procesního řízení ve firmě, Praha: Grada Publishing, 2007. p.300. ISBN 8024716794.

\section{Primary Paper Section: A}

Secondary Paper Section: AE 